\title{
Application Research of Situational Simulation Exercise in College Oral English Teaching
}

\author{
Sa Xie \\ Hainan Science and Technology College, Haikou, 570208, China
}

Keywords: Sitiational simulation exercise, Process, Implementation, Research

\begin{abstract}
Situational simulation exercise is to contrust a funny and interesting contexts through hypothesis, and let students to participate different roles in contexts, is a new teaching method. Foreign language teaching should focus on theri listening and speaking ability, and strengthen their vatality and learning enthusiasm through situational simulation exercise. This paper makes some research on the application of situational simulation exercise in college oral teaching through the analysis on its development and features.
\end{abstract}

\section{Analysis on situational simulation exercise}

The proposal and development of situational simulation exercise

The situational simulation exercise in management science is proposed by Hartshorne (American psychologist), it refers to design the corresponding questions by their position, and instruct an work context for them to deal with those difficulties which they will face to. The aim is to detect those candidate's ability. As it improves, this method has spread to the education science from management science, is called specific way of teaching. The concrete things are that students would take some practical study in those established simulation scenarios, also it is a interactive method of teaching of enhancing student's communication skills. As an English professor of Tsinghua University, Shisheng Liu suggests that situational teaching refers to students take some role in designed and real situation.

\section{The features of situational simulation exercise}

This simulation teaching would construct some contexts in which students will play some specific roles to exercise their ability and quality level. Specifically speaking it, there are three features as fllows:

1). Interactivit. students would take some practical study in those established simulation scenarios, also it is a interactive method of teaching of enhancing student's learning enthusiasm. Unlike the previous, this new teaching method insist to develop teaching through practice, and exercise through simulation, and develop student's activity and creativity.

2). Interestingness. The previous teaching focus on understanding professional knowledge and skills. The common status is to recite those basic knowledge, and it is very drying so that students have low mental status of learning. On the contrary, the situational simulation exercise would guide students to attend the simulative pratice, and exercise their professional skills instead of the previous. It is a interesting method of learning.

3). Practicability. The situational simulation exercise would contruct some commin scenarios, such as student's role is a Chinese visitor to England, he need to ask the location of toilet. Throug it ,students would learn some oral communicative english, this is the real effect.

The necessity of the situational simulation exercise

Language is a practical tool. Language teaching should emphasize student's ability of listening and speaking and provide service to language communication and social skills. However, dumb English is the common thing, students only understand english by memorize those grammer mechanically, they are lack of ability of communication. From this angle, the whole language teaching is not scientific. The situational simulation exercise presents that the blend of language and situation is the reason for the interpersonal relationship, so we need to consider learn english in simulational teachin. The integration of language and situation could promotes each other, this is essential; the secondly, only by simulational teaching we could understand language well. Therefore, 
language could not achieve its function of communication without its specific situation, it is important to make situational simulation exercise.

\section{The implementing measures of situation simulation}

We have known the necessity of situation simulation. To understand more about situation simulation ,we make an analysis on the implementing measures, as follows:

Situation simulation with the pratice in textbook

Textbooks are resources of teaching, it has summarized some important knowledge point. We could find some typical example and situations through understanding of textbooks. These could help conntructing those situation. These situations would not only about teaching contents, but also help students to review and understand. By these situations, teachers could consider the way of group division and role-playing, it will help students to understand knowledge point and increase their speaking ability on the basis of textbook.

Situation simulation with life reality

Life is full of situations, not only the daily conversation, but also simple communication. We contruct situation with life reality would be easily accepted and have realistic meaning. Students would exercise their oral english and enhance their confidence through simulation about daily affairs.

Situation simulation of teaching through lively activities

The old method of memory is too boring. To stenghten its interestingness, we need to design games or activities which confort students, and guide them to attend those activities. By this way, it could enhance student's learning interestingness and exercise their speaking ability.

Situation simulation with new teaching tools

The situation simulation in calssroom always suffer limits of time and space, and these simulations could not express the whole plots. It is essential to use some new teaching tools and apply electron teaching, such as record, vedio and projector, to attract students.

Design situation simulation with though extensibility

People have extensibility in thoughs, which is called "trace to its source", refers to people would associate other relevant things actively and pay attention to them after they knew something. Against thise feature, it is interesting to develop scenarios after we contruct some situations. For example, we imagine their married life about Cinderella and Prince. This story is popular and is easy to participate in, and this situation would satisfy people's thoughs about knowing some more informations. So it could enhance student's joining passion.

Situation simulation by group competition

We divide those studetns into some groups, and let them attend competition in groups, and make some evaluation. This way could not only enhance student's consciousness of competition and cooperation, but also make everyone in group perform well.

Situation simulation with ambient scene

Guiding students out of the classroom, could help them feel abundant social life and natural scenery. It is more intersting in ambient scene than in classroom for students to attend situation simulation. It also helps to enhance student's learning interestingness and exercise their speaking ability.

\section{Analysis on implementation of situation simulation}

\section{The problems in implementation of situation simulation}

As the situation simulation steps to classrooms, but the results are not good as it is anticipated. There are four questions in spoken language teaching.

Ambiguity of the objective

Although students and teachers know the aim of spoken language teaching is to increase student's ability of speaking and listening, but every students have their own foundation. For the reason that teachers are required to apply foreign language teaching in university, it will lead some students to 
learn english difficultly. As time passes, these people with low foundation would hate english and not willing to train their spoken languag.

\section{Less attention on student's feedback information}

Spoken teachers will pay major attention to their knowledge and technological process, and rarely interact with their students. So the situation simulation could not effective, and student's feedbak information would not be concerned, then make some difficults.

The formalization of simulation activities

Every people have known the importantance of simulation activities to spoken teaching, but teachers always arrange more people to participate traning in limited time. Take self-introduction for example, every student only be divided a few minutes. To ensure evertone could attend this activity, one by one, students always could not ensure their correct pronunciation. Therefore, this formalized simulation activities could notexercise their speaking ability, but easy to waste time.

Lackness of "individualized teaching" in education

There are a thousand Hamlets in a thousand people's eyes. This way of using one method to educate all the students is not scientific. Students have different fundations of english and have different ability of learning which will result in students learn new knowledge with different speed. If we force some students with low foundations to attend simulation activities, students would feel embarrassed, and teachers would not satisfy this teaching way. As a result of that, the application of simulation activities should be "individualized teaching".

\section{The implementation significance of situation simulation}

\section{Stimulating student's interest}

Interest is the best teacher. Students play different roles in different and interesting simulations activities, it is a hard challenge. To exercise their spoken ability in interesting simulations activities, and use those learned knowledge consciously, and also transfer the knowledge to ability of exact expression, these are behaviors of situation simulation.

Enhancing student's imaginal thinking and active study ability

Simulation activities are closed to life reality, these things are common and have strong visual impression. To participate these realistic simulation activities will easily help student develop their imaginal thinking, and we could apply many methods, such as PPT explanation, group discussion and panel discussion, these way all could help students promote their consciousness of cooperation and active study ability.

Enhancing student's ability of analyzing and solving problems

Make situation simulation, help students to attend learning actively. They will consider their role and behavein the similation activities. So it could enhance student's ability of analyzing and solving problems and help them to understand different role's social function and make them learn and analyze actively.

Strengthening student's ability of speaking

Foreign teaching could not be separated with training of speaking and listening. Usage of situation simulation could note only help students to develop social consciousness, active learn and analyze ability, and the most important aim is to develop student's ability of speaking. To express their words in setted situation, and transfer the wirting knowledge to oral expression, and strengthen their using ability, and also could help them to express what they have thought and use what they have studied.

\section{The implementing emphasis of situation simulation}

\section{Definite requirements}

Teachers should consider the attendence of those students which have low listening level, they could speak slowly and describe for more times and explain these difficulties, the aim is to make sure every student could understand and participate. Only by this way, every student could be willing to participate and cooperate with teachers passionately.

\section{Concise expression}

Teachers should describe similations, answer student's questions with the most familar and concise language. They should make sure every student should keep pace with them. Only by this way, teachers could communicates with students and promote their ability. 


\section{More encouragement}

Some students with low ability always behave timidly and unnatural, and they may be more shy if they behave not good. For these students, teachers should guide them to speak more and listen their suggestions and make more encouragement.

Avoid the formalization

As far, there are many examples about situation simulation, but most of them become a mere formality, and ignore its effect of enhancing student's thinking and expressing. In teaching process, we need to be not hasty. There are more methods, such as group cooperation and group competition. We also need to avoid those formalization. Only by this, we could exercise student's ability of cooperation and speaking, and also promote their benign competition.

\section{Summary}

In conclusion, the situation simulation could mobilize their enthusiasm of learning and enhance their ability of independent study. In spite of there are some problems, such as ambiguity of the objective, less attention on student's feedback information and the formalization, but the situation simulation also could help to contruct atmosphere, stimulate their enthusiasm for learning. It is because its importance that we need to find out disadvantages and improve them.

\section{References}

[1] Xiaoqin Fei, The application of situational teaching approach in college English teaching. Anyang Normal Univerisity, 2014(6):142 - 143.

[2] Li Zhang, The effect of situational teaching approach in college oral English teaching”. Henan Mechanical Electrical Secondary School. 2013(5):87-89

[3] Yongyi Yan, The research of situational teaching approach in English teaching, Journal of Chifeng College (Natural Science Edition). 2014(18):30-35

[4] Mengmeng Huang, The application of situational teaching approach in classroom. Compus English, 2012(11):35-36

[5] Yuanyuan Wang, The application of situational teaching approach in middle school classroom, Charming China. 2013(3):20-25 